\title{
The Hinterland of the Newsletter: Handling Information in Space and Time
}

\author{
Mark Greengrass, Thierry Rentet and Stéphane Gal
}

There is an emerging orthodoxy in our understanding of how early-modern information became news. 'Information', in this context, refers to what is learned, processed and stocked from others, and whose worth is related to the rarity value that it possesses. 'News' is its subsequent transmission into another, possibly more public, environment. That orthodoxy relies on several elements, which generate, in turn, a chronology of change. ${ }^{2}$ Firstly, there was

1 These definitions are discussed in Michel Serres' lecture to the University of Paris on 29 January 2013: <www.sorbonne.fr/michel-serres-prononce-en-sorbonne-la-conference -inaugurale-du-programme-paris-nouveaux-mondes/> [20/1/15].

2 See various studies and edited works, referred to elsewhere in this collection, e.g. C. John Sommerville, The News Revolution in England: Cultural Dynamics of Daily Information (Oxford: Oxford University Press, 1996); Joad Raymond, The Invention of the Newspaper: English Newsbooks, 1641-49 (Oxford: Oxford University Press, 2005); Bob Harris, Politics and the Rise of the Press: Britain and France, 1620-180o (London: Routledge, 1996); Gilles Feyel, L'Annonce et la Nouvelle. La Presse de l'information en France sous l'Ancien Régime 1630-1788 (Oxford: Voltaire Foundation, 200o); C. Berkvens-Stevelinck, H. Bots, Paul G. Hoftijzer, and O.S. Lankhorst, eds., Le Magasin de l'Univers-The Dutch Republic as the Centre of the European Book Trade (Leiden: Brill, 1991); Johannes Weber, 'Avisen, Relationen, Gazetten. Der Beginn des europäischen Zeitungswesen', in Bibliotheksgesellschaft Oldenburg. VorträgeReden—Berichte, ed. H. Brandes and W. Kramer, No. 20 (Oldenburg: Bis, 1997); Johannes Weber, 'Der große Krieg und die frühe Zeitung. Gestalt und Entwicklung der deutschen Nachrichtenpresse in der ersten Hälfe des 17. Jahrhunderts', Jahrbuch für Kommunikationsgeschichte, ed. H. Böning, A. Kutsch and R. Stöber, vol. 1 (Stuttgart, 1999); Brendan Dooley, 'De bonne main; les pourvoyeurs de nouvelles à Rome au XVIIe siècle', Annales: Histoire, Sciences Sociales, 54 (1999), 1317-44; Brendan Dooley and Sabrina Baron, eds, The Politics of Information in Early Modern Europe (London: Routledge, 2001); Mario Infelise, Prima dei giornali. Alle origini della pubblicainformazione(Romeand Bari:Laterza, 2002);JohannesWeber, 'Kontrollmechanismen im deutschen Zeitungswesen des 17. Jahrhunderts. Ein kleiner Beitrag zur Geschichte der Zensur', Jahrbuch für Kommunikationsgeschichte, ed. H. Böning, A. Kutsch and R. Stöber, vol. 6 (2004), pp. 56-73; Francisco Bethencourt and Florike Egmond, eds., Correspondence and Cultural Exchange in Europe, 1400-1700 (Cambridge: Cambridge University Press, 2007); Brendan Dooley, ed., The Dissemination of News and the Emergence of Contemporaneity in Early-Modern Europe (Aldershot: Ashgate, 2010); Andrew Pettegree, The Invention of News. How the World Came to Know About Itself(London: Yale University Press, 2014).

(C) MARK GREENGRASS ET AL., 2016 | DOI 10.1163/9789004277199_028

This is an open access chapter distributed under the terms of the Creative Commons Attribution-

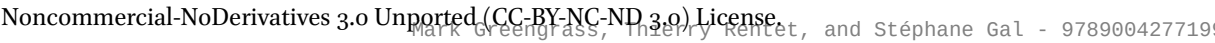


the emergence of a group of specialists in the gathering of information, its collation, evaluation, filing, and subsequent transmission as news. Secondly, that specialism grew out of an increasing density of information and, with it, a concomitant and inevitable growth in the circulation and credence accorded to rumour and gossip. That density was, in turn, the result of fundamental changes in information dynamics, which were the consequence of the consolidation of print culture, the embedding of letter-circulation and postal communication as a means of exercising power at a distance and as a medium of cultural exchange, changes in Europe's knowledge horizon, and in the power of the state. Thirdly, the sophistication of these information practitioners depended on their ability to sift out personal or private information from matters of public importance, and to evaluate different sources of information in accordance with criteria based on experiential reliability. Their experience taught them how to triangulate between conflicting stories, and to be prudent in drawing conclusions based on only one source. Fourthly, the resulting news was valuable to those whose fortune and position ensured privileged access to it- to governing entities and commercial stakeholders. However, it also had value to those involved in print culture-writers, printers, publishers and distributors - those for whom a market in news had grown up in the course of the sixteenth century. Other emporia emerged for official information (published edicts, municipal ordinances, ecclesiastical placards, etc.), and religious polemic (libels, pamphlets, etc.). Each had its factors. Newsletter-writers and secretaries, printers, publishers, and distributors, pamphleteers and libellistes operated in a world in which official censorship was ill defined and irregularly enforced by a patchwork of overseers. The real constraints on what one could disseminate lay in the politics of the information moment. They determined what could be circulated in a particular circumstance, how it should be presented and circulated, by whom, and the reactions of those who received it. These key elements are used to account for the emergence, firstly, of manuscript newsletters (avvisi) in the information centres of the Italian peninsula in the sixteenth century and their subsequent migration into manuscript newsletter services in northern Europe. The concomitant growth in printed news pamphlets across a broader European geographical spectrum and over a longer chronology provides a further, linked, component to that of the avvisi. The 'invention of news' (in the form of a recognisable periodical press in the first half of the seventeenth century) is, therefore, the outward and visible sign of fundamental changes to the dynamics of information in early modern Europe. These changes had been underway for a long time. They marked a profound shift in the perception of what it was to be 'contemporaneous'. 
This paper does not call into question that consensus. It simply suggests that we should not allow commercial logic, or the surviving artefacts of distributed news (in manuscript or printed forms) whose emergence it seeks to explain, to obscure an underlying reality. All correspondence networks were, ipso facto, transmitters of information and instruments of cultural exchange. Those who managed the flows of information within them were specialists in the handling of information. Conventions and expectations in the correspondence networks to which they belonged determined their behaviour. That was a market of sorts, albeit a closed one. It dictated what they sent on, or kept to themselves, and how they evaluated and presented the information that came their way. These correspondence networks constitute what we shall describe here as the 'hinterland' of information from which news was fabricated. By concentrating on the information-gatherers and disseminators in a public context — the avvisi writers, publicists and polemicists, etc. — we are in danger of ignoring those who were still the overwhelmingly important forces in the handling of information and the dissemination of news. Those preeminent figures were the 'court pieces' on the information 'chess-board' - the senior clerics and grandees, favourites and hangers-on who inhabited princely courts. Manuscript avvisi were principally produced by those in the service of princes. The avvisi writers frequented grandees in search of information and syndicated the results to diplomats, councillors and advisors in the courts of other princes.

In the sixteenth-century French context, which is where this paper is located, noble correspondence has been utilised heretofore to furnish evidence for the fundamental importance of informal power structures in Renaissance France. It documents the significance of the noble household, the flexible and contingent relationships between grandees and their patrons and clients, and their cultural and artistic mécénat. ${ }^{3}$ These structures were equally determinant, however, as information networks. Through them, prominent

3 Sharon Kettering, 'Clientage during the French Wars of Religion', Sixteenth Century Journal, 20 (1989), pp. 68-87; Mark Greengrass, 'Functions and Limits of Political Clientelism in France before Cardinal Richelieu', in L'Etat ou le Roi:fondations de la modernité monarchique (XIVe-XVIIIe siècles), ed. Neihard Bulst, Robert Descimon and Alain Guerreau (Paris: Editions de la Maison des sciences de l'homme, 1996), pp. 69-82; Sharon Kettering, 'Friendship and clientage in early-modern France', French History, 6 (1992), pp. 139-58. For particular examples, see (among others), Mark Greengrass, 'Noble Affinities in Early Modern France; the case of Henri de Montmorency-Damville, constable of France', European Studies Quarterly, 16 (1986), pp. 275-311; Ariane Boltanski, Les ducs de Nevers et l'état royal. Genèse d'un compromis (ca.1550-ca. 16oo) (Geneva: Droz, 2006), esp. part II; Stéphane Gal, Lesdiguières. Prince des Alpes et connétable de France (Grenoble : Presses Universitaires de Grenoble, 2007), 
French princes promoted their own lineage and 'identity capital.' 4 Operating in a world of intense rivalries, higher nobles in French politics instrumentalised debates in sixteenth-century France in order to discredit their rivals. They conducted campaigns of libels (i.e. 'pamphlets') and publicised their lawsuits in 'factums.' They chose deliberately whether, when, and how to engage in a libel campaign, such decisions being a determinant in the polemical strategies that accompanied their own political engagements. Their secretaries, lawyers and agents were the information specialists who managed and collated their correspondence networks, acting as their publicists, and deploying news as best served their masters. Others - family members as well as their servantsplayed a role that involved information gathering, collation, analysis and dissemination. They made use of the royal postal services, whose operation they oversaw as provincial governors and lieutenants. However, they also had their own private couriers and messengers, upon whom the French state also depended. The more developed that state became, the more it drew upon intermediaries - magistrates, specialists of one sort or another, military officers, etc. Those intermediaries constituted an important 'public' in the 'market' for news. So there was no definable line between what constituted private information and published news because what circulated within the networks of those who were royal servants was also what became diffused as 'news' in a more public sense. What passed from one party to another on its way to and from court was rapidly disseminated more broadly. Clienteles within the upper nobility functioned like echoic chambers. News in one quarter was rapidly picked up and relayed to other quarters. The functioning reality of noble clienteles rested upon informal information and communication as well as power structures.

$$
* * * * *
$$

The surviving correspondence of a grandee in sixteenth-century France over a period of six months during the year of the massacre of Saint Bartholomew (1572) furnishes the evidence to substantiate these propositions. The Gordes

esp. part IV; Thierry Rentet, Anne de Montmorency, grand maître de François Ier (Rennes: Presses Universitaires de Rennes, 2010).

4 Eric Durot, François de Lorraine, duc de Guise entre Dieu et le Roi (Paris: Garnier, 2012), esp. part I.

5 Tatiana Debbagi Baranova, A coups de libelles. Une culture politique au temps des guerres de religion (1562-1598) (Geneva: Droz, 2012); Marie Houllemare, Politiques de la Parole. Le Parlement de Paris au XVIe siècle (Geneva: Droz, 2011), pp. 331-43. 
were an old noble family from southeastern France whose origins lay in the county of Provence. The family was prolific, its branches serving as the major boughs of the Provençal nobility (the Houses of Agoult and Pontevès). Meanwhile, through the line of Simiane de Gordes, they extended their influence and connections into Dauphiné and the Piedmont region of the duchy of Savoy. ${ }^{6}$ Bertrand Raymbaud v de Simiane, Baron de Gordes succeeded to those family connections through his father (Bertrand-Rambauld IV), and his mother (Perette de Pontevès). ${ }^{7}$ Born on 18 November 1513 , he became the eldest scion of 18 children. Five brothers became Knights of St John of Jerusalem or of Malta-all of them dying in military service against the Ottomans. A sixth served in the French cavalry and was wounded in the French Civil Wars at the battle of Moncontour (1569). Three further brothers entered the Catholic Church whilst the youngest brother of all (Aymar) settled into the life of a Dauphiné nobleman. The churchmen became (paradoxically) the most susceptible to Protestantism. Two of them openly declared their Calvinist allegiance in the 1560s. By the year of the massacre of Saint Bartholomew (1572), the Simiane de Gordes clan had a foot in both camps. Bertrand-Raymbaud v's enemies criticised him for his divided loyalties. However, such connections and family links to the Protestant noble leadership were a valuable asset to those at the French court who tried to set in place a political reconciliation to the Civil Wars. They were in the ascendant in the wake of the Peace of SaintGermain (August 1570).

Bertrand-Raymbaud v's career begun with distinguished service on the battlefield, but he owed his political ascension to Anne de Montmorency, Grand-Maitre and then (in 1536) Constable of France, who reached the apogee of his influence with the accession of Henri II to the throne in 1547. Montmorency schooled him in a prudential approach to diplomacy and statecraft. No stranger to the Valois court, Gordes' appointment as lieutenant-général in Dauphiné in October 1564 was, nevertheless, contentious. The events of the first Civil War $(1562-3)$ in Dauphiné had been divisive. ${ }^{8}$ The fault lines had long been set in

6 François Alexandre Aubert de la Chesnaye-Desbois, Dictionnaire de la Noblesse ... de France, 19 vols. (Paris: Schlesinger frères, 1863-77), 15:599-621. The great eighteenth-century genealogist rarely admitted defeat, but he met his match with the Simiane: "On ne trouvera point ici l'histoire des maison d'Agoult \& de Pontevez, sorties de la maison DE SIMIANE, l'éxécution en seroit trop vaste \& demanderoit un volume entier".

7 Paul Prallat, Bertrand Raimbaud de Simiane, Baron de Gordes, Seigneur de Laval—ou La Balade entre les Croix (Laval: Editions Horizons. Autrefois pour Tous, 2013), pp. 6-13.

8 The narrative sources for these events include Nicolas Chorier, Histoire générale du Dauphiné (Lyon, 1672), books 16- 17; H. de Terrebasse, Histoire et généalogie de la famille de Maugiron (Lyon: Librarie Ancienne de Louis Brun, 1905); Pierre Cavard, La Réforme et les guerres de religion à Vienne 
place-geographically between the foothills of 'lower Dauphiné' and the mountains of 'upper Dauphiné', linguistically (French, francoprovençal, and langue d'oc), and fiscally (part of the province was a zone of 'taille personnelle', and part of it 'taille réelle' - with substantial consequences for how people were taxed). Dauphiné lay wide open to the confessional divisions that characterised the early Civil Wars because it lay on the route-way between Geneva and southern France and because it had the remnants of a mostly-suppressed Vaudois movement that had aligned itself with Geneva. On the eve of the civil wars, 40 or so Protestant churches were established (i.e. had a consistory) in its urban environments.

The politicisation of Dauphinés Protestants occurred rapidly in the years from 1560 to 1562 . That was in response to unfolding national events. Locally, the pattern of iconoclastic destruction that took place bore the hallmarks of a movement that threatened to spin out of the control of its consistories and synods. The dynamism of Dauphiné Protestantism came partly from its lesser nobility, among whom the new religion had found a hearing, and who proved themselves in due course capable of putting together a regional military organisation. In the first civil war, Dauphiné's militant Protestants, led by François de Beaumont, Baron des Adrets, captured the towns on the Rhône/Isère arterial axes. They looted church wealth and destroyed ritual objects, aiming to rid the province of papal pollution and instigate a new order, but also to provide the resources for their military campaign. They terrorised Catholics into submission or into exile in nearby Piedmont or the Comtat Avignon. The king's lieutenant-général (Blaise de Pardaillan, sieur de la Motte-Gondrin), a newcomer to the province and without loyalties among its noble clans, was assassinated early on in the hostilities (in Valence on 27 April 1562). His replacement was Laurent de Maugiron, someone whose family, career and aspirations bear comparison with those of Gordes. Maugiron's instructions from the young King Charles IX included an explicit mandate to apprehend the Protestant leader (des Adrets) held responsible for La Motte-Gondrin's death, or otherwise avenge it. With royal authority crumbling around him in the face of a determined Protestant opposition, Maugiron had little choice but to make the most of his connections with the governor of Dauphiné at the time of his appointment

(Vienne: Blanchard Frères, 1950); cf Nicolas Danjaume, 'La ville et la guerre. Valence pendant la première guerre de religion (vers 1560-vers 1563)' (Mémoire de maitrise, sous la direction de Stéphane Gal, Grenoble II, 2009); Christophe Vyt, 'Liconoclasme huguenot à Vienne [Isère] pendant la première guerre de religion', Bulletin de la société des amis de Vienne, 95 (2000), pp. 3-37; and, for Protestant organisation in Dauphiné within the national context, Philip Benedict and Nicolas Fornerod, eds., L'organisation et l'action des églises réformées de France (Geneva: Droz, 2012). 
(François, Duke of Guise), and to rally the province's remaining committed Catholics behind a bruising military campaign in the summer of 1562 . The Peace of Amboise (March 1563) ended these first hostilities, but Maugiron's reputation as a Catholic hardliner compromised his efforts to enforce the pacification. The new governor in Dauphiné (the prince of la Roche-sur-Yon, in succession to François, duke of Guise, assassinated in February 1563) persuaded Catherine de Médici that the best way of calming Dauphiné's Protestants was to instigate a shared lieutenancy, putting in place in lower Dauphiné someone who would be more emollient in their eyes. Maugiron rejected that proposal, arguing that he could not serve a governor who had shown no confidence in him, and that "to have two people governing a province was to put disunion among its population". 9 His disgrace triggered Gordes's appointment. However, the shadow of Catholic resentments pursued Gordes throughout his period of office. Although he remained lieutenant in Dauphiné through to his death in 1578, Maugiron's friends and supporters periodically orchestrated whispering campaigns against him, turning his conciliatory moves towards Dauphinés Protestants into signs that he had failed to stand up for the royal (and Catholic) interest.

Regional specialists already know this political background. Hardly explored at all, however, are the 31 volumes of Gordes correspondence, covering (with some gaps) his period in office as lieutenant in Dauphiné from 1565 to 1576 . The overwhelming majority of the over 7,00o items in it are letters written to Gordes. They are part of the muniments of the Condé family in the manuscript collections of the archives at Chantilly because in the eighteenth century Marie-Thérèse de Pontevès de Simiane, Gordes' descendant, left her inheritance to Charlotte, daughter of Charles de Rohan-Soubise, who married Louis-Joseph, Prince de Condé in 1753. Although Condé subsequently (1787) sold the Gordes-Laval estates, the family papers had already been transferred to Chantilly, which is where they have remained ever since. Even though the survival patterns are quite irregular, indicative of various gaps, this is quite simply the largest surviving letter collection from a provincial lieutenant in France during the sixteenth century (see Figures 27.1-27.4, below).

From this archive, we can study the collection, collation and transfer of news. Dauphiné played a significant role within the information structures of the French state. It was a nodal point for both international and regional information traffic. On the one hand, it was the receptor for news coming from the Italian peninsula and from the Mediterranean to France. Much of the courier traffic between Rome, Venice, Genoa and Turin and France passed through Dauphiné. So, too, did some of that between France and the Swiss cantons.

9 Maugiron to Catherine de Médici, Vienne, 20 December 1566, cited Terrebasse, Histoire et généalogie, pp. 109-10. 


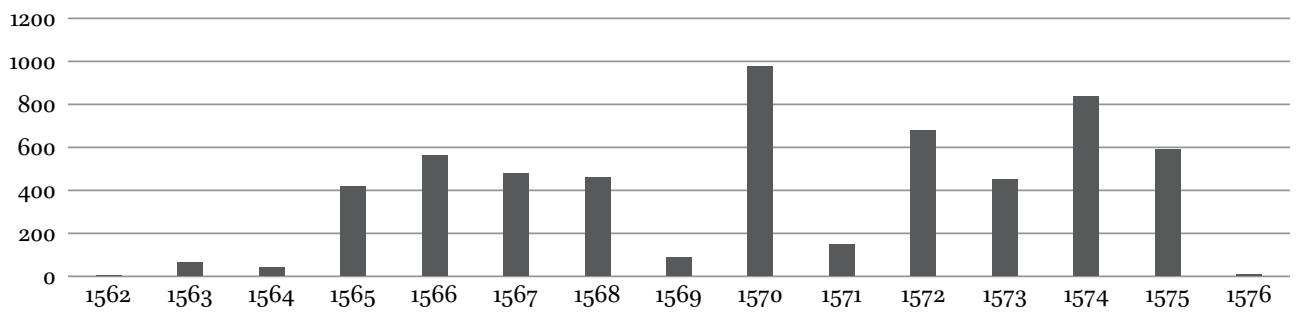

FIGURE 27.1 Surviving volumes of material in the Gordes Collection, Chantilly (Archives de Chantilly, Series K, vols 1-31)

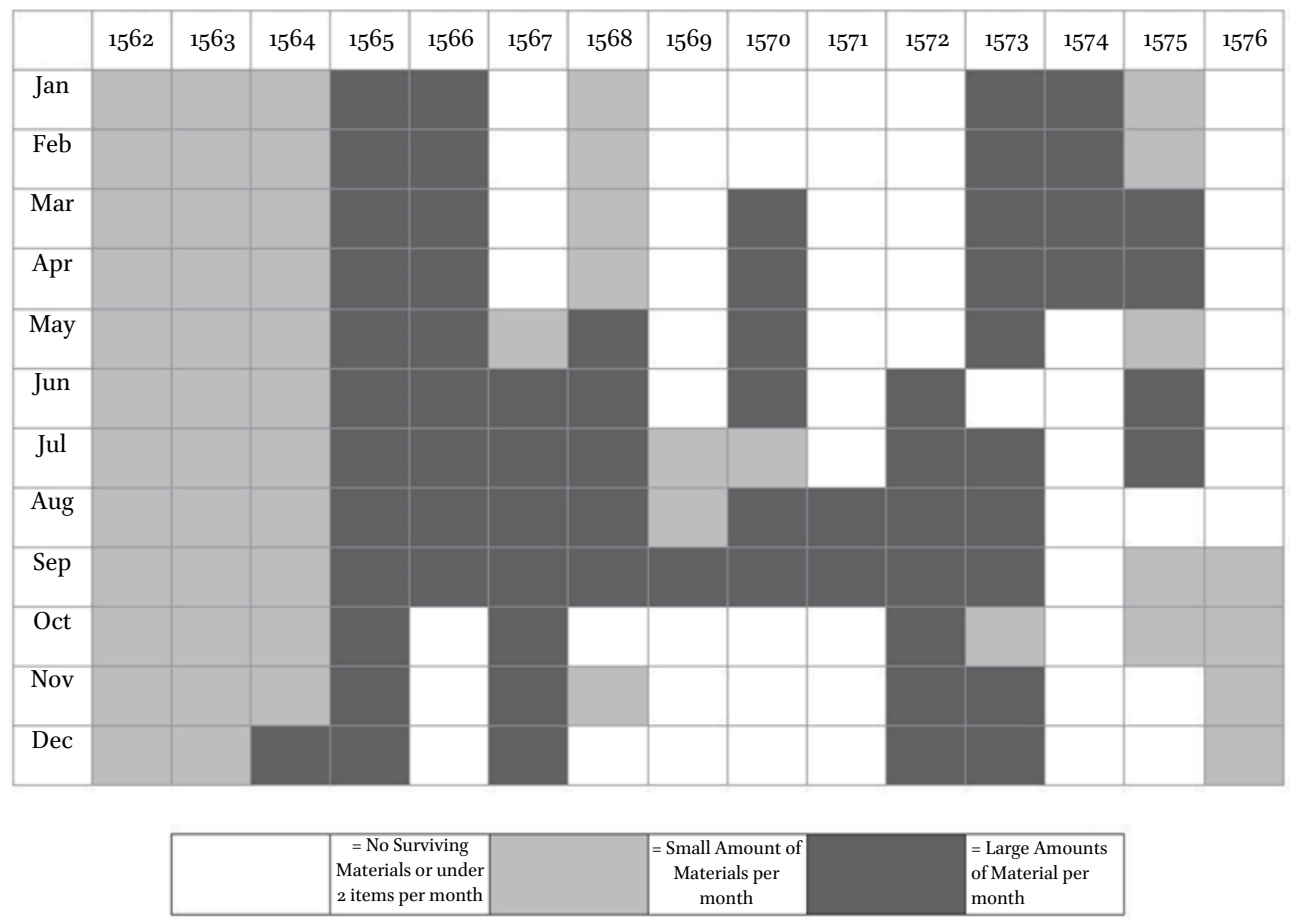

FIGURE 27.2 Surviving volumes by month

At the same time, couriers from the Iberian peninsula to the Rhineland and the Netherlands passed up the Rhône valley on their way northwards, except in times of war. Carriers also brought post and news through Dauphiné to and from Rome for the independent Papal enclave of Avignon and the Comtat Venaissin, and to and from William and Louis of Nassau to their little principality at Orange. Couriers (chevaucheurs) were often stopped and interrogated, and their despatches opened and read. Dauphiné was therefore a listening-post for what happened internationally. That information in turn shaped Gordes' own approach to governing his province whose security depended on what was 
happening in the wider world. Gordes received pamphlets (pasquins) from Rome and reports (avis) from Milan, Genoa, and Turin. ${ }^{10}$ With the Protestant politico-military organisation in southern France in contact with the Protestant Swiss cantons and German princes, he was also kept abreast of developments in those parts. ${ }^{11}$ This was not news from syndicated sources. It simply arrived in the despatches to him. But because there are so many similarities of form and analysis to the way in which his correspondents framed their letters and the way in which newsletters are constructed, we may say that the letters of those in authority like Gordes constitute a kind of 'hinterland' to the newsletters with which this volume is mostly concerned.

We have chosen to analyse how information was gathered and circulated in the Gordes network by concentrating on the months from June to December 1572. We have transcribed the 672 despatches and appendages of that year. ${ }^{12}$

The surviving letters are evidently incomplete. The modest number for the month of September - the first full month after the massacre of Saint Bartholomew-is particularly striking. The extreme sensitivity of that moment implies that there was selective removal from his papers at that date.

On the international scene, the members of Gordes' network monitored three interlinked theatres: the disposition of armed naval fleets in the Mediterranean in the year after the Battle of Lepanto; the despatch of Spanish troops through Milan up the 'Spanish Road' to the Netherlands, and the developments in the rebellion of the Dutch. Regionally they focused on the garrisons and strongholds and the implementation of the terms of the latest edict

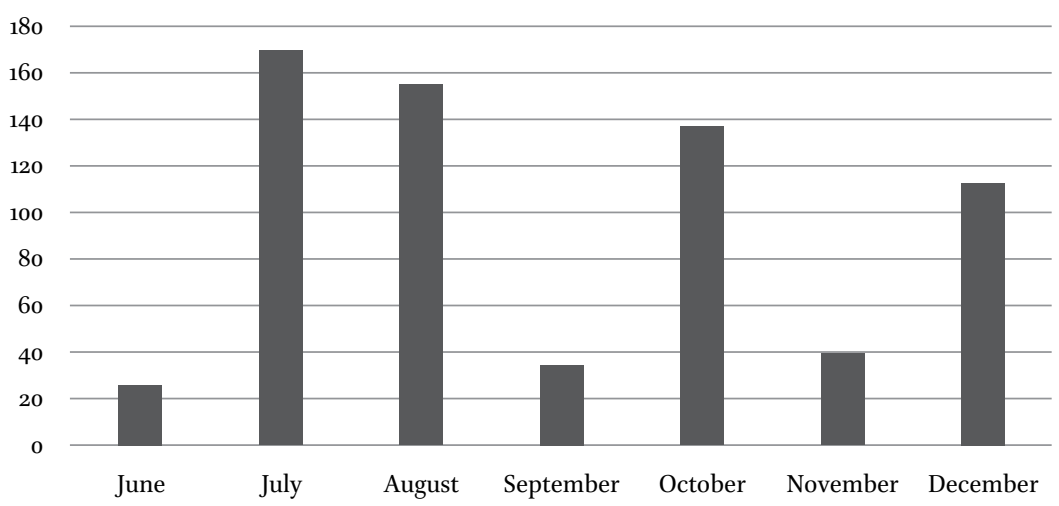

FIGURE 27.3 Monthly distribution of material in the Gordes Collection, June-December 1572 (ACKXVII-XIX)

10 Archives de Chantilly Series K [henceforth ACK], VI-343 (pasquins de Rome, n.d.); XVII222 (Genoa, 4 June 1572); XXII-103 (Milan, [1574]); XXII-16 (Piedmont, [1574]).

11 ACK XXX-228; $-229 ;-298,-299$.

12 ACK XVII-XIX. 
of pacification (Saint-Germain, August 1570). Those concerns modulated in the wake of the massacre of Saint Bartholomew (24 August 1572) into surveillance of the reactions of Dauphiné's Protestants and their mobilisation in the light of unfolding events in Lower Languedoc, where their co-religionists broke out in revolt in late October 1572. Gordes was mostly in Dauphiné, either in Grenoble or at Laval, where the family had a château, not far from the provincial capital. In October, however, he visited Lyon in order to meet Henri de MontmorencyDamville, bound for Languedoc in anticipation of the coming insurrection. In December, he briefly visited his relatives in Chambéry. We can establish his whereabouts from the endorsements on the incoming correspondence (see Tables 27.1 and 27.2, below).

A great deal of information was communicated orally. What we might regard as a postal system was, in reality, a way of conveying individuals who sometimes

TABLE 27.1 The movements of the Baron de Gordes (July-December 1572).

\begin{tabular}{ll}
\hline 5 Jul 1572 & Grenoble \\
7 Jul 1572 & Allières \\
9 Jul-26 Jul & Grenoble \\
26 Jul-19 Aug & Laval \\
19 Aug & Moirans \\
19 Aug-25 Aug & Laval \\
26 Aug & Grenoble \\
$27-9$ Aug & Moirans \\
1 Sep-23 Sep & Laval \\
24 Sep & Grenoble \\
$25-6$ Oct & Laval \\
$6-8$ Oct & Grenoble \\
11 Oct & Lyon \\
15 Oct & Vienna \\
16 Oct & Tournon \\
17 Oct & Valence \\
$19-22$ Oct & Montélimar \\
25 Oct-2o Dec & Grenoble \\
$20-22$ Dec & Chambéry \\
22 Dec & Fort Barraux \\
23 Dec- & Grenoble \\
& \\
\hline
\end{tabular}


relayed information verbally, and at other times carried letters. There were limits to what it would be prudent (or even practical) to say in a letter. Although letters travelled closed and sealed, that was no guarantee that their contents would not be discovered. The second président of the Parlement in Grenoble, Guillaume de Portes, opened even closed letters addressed to Gordes. His colleague, Jean Truchon, in receipt of closed letters addressed to him from the Protestant gentry of the Grésivaudan in December 1572 decided he should open them in case they contained "quelque chose de pressé" ("something important"). ${ }^{13}$ Gordes' correspondents regularly acknowledged the dates of those to which they were replying, so that the sender could make a tally.14 Even if despatches were not opened, a carrier was often expected to reveal the subscription (or 'address') on the despatch. ${ }^{15}$ The senior law officers of the Parlement distributed royal letters, intended initially for the lieutenant. In October 1572, the second président even suggested to Gordes that he circulate a recent letter from His Majesty around the lesser jurisdictions of the province but with the last paragraph omitted because he felt that it might inflame Protestant sensibilities. ${ }^{16}$ Gordes' correspondents were often concerned to have the latest news. They regarded information as a gift, a sign of loyalty and dedication to the lieutenant's (and royal) service. What they chose to pass on involved a judgment call as to what was 'rare', i.e. worthy of his attention ("dignes de vous"). The postal network was in some ways an extension of Gordes' own affinity.

The origins of that network lay in the establishment of post-horses at relay stations on the principal highways by Louis XI by an edict of 19 June $1464 \cdot{ }^{17}$ Postmasters received a small annual recompense as well as a fee for each relayhorse deployed. Despite its distance from Paris (almost 6oo kilometres), Grenoble was well served by the royal posts. The route from Paris to Lyon was "le principal voyage et plus fréquenté" ("the principal and most travelled way") in the kingdom. Although the cost of sending despatches to Grenoble, involving 38 relay stations and one river crossing (at Roanne), was high, despatches

\footnotetext{
13 ACK XIX-321 (Jean Truchon-Gordes, Grenoble, 22 December 1572).

14 E.g. "La dernière de mes lettres nestoyt que pour accompaner et, comme disent les Modernes, accuser la reception dun pacquet" ("My last letter was only to accompany and, as they say these days, acknowledge receipt of a packet") - ACK XIX-92 (Guillaume de Portes-Gordes, Grenoble, 13 October 1572).

15 ACK XIX-30 (Guillaume de Portes-Gordes, Grenoble, 3 October 1572).

16 ACK XIX-45 (Guillaume de Portes-Gordes, Grenoble, 5 October 1572).

17 Eugène Vaillé, Histoire générale des postes françaises, 6 vols. (Paris: Presses Universitaires de France, 1947-55), 2, 24-37; John B. Allen, 'The Royal Posts of France in the Fifteenth and Sixteenth Centuries', Postal History Journal, 15 (1971), pp. 13-17.
} 
were regularly conveyed at an impressive rate. ${ }^{18}$ Lyon was an information capital in sixteenth-century France. Its merchant banking communities had regular and excellent connections through their factors to the main commercial centres of the Italian peninsula, Germany and the Swiss cantons. Its bankers served as intermediaries with Rome for the provision of benefices and the payments of annates (annatae). Gordes periodically received reports (avis) from Lyon on the latest international information. ${ }^{19}$ When Antoine Grolier, a member of a prominent Lyon family, replied to a letter from the Dauphiné lieutenant on 11 July 1572, he chose to do so in the form of a précis of the information that had arrived into the city over the previous six weeks. It began with a paragraph on the news from Constantinople (in a despatch from the French ambassador, François de Noailles, bishop of Dax), continued from another from Rome (via a nephew of François Rougier, sieur de Malras, the serving French ambassador to the Curia). Others followed with news from Venice, Antwerp and Paris-precisely in the form of a newsletter. ${ }^{20}$

Charles Estienne's 1553 Guide des Chemins de France describes the postroads that went forward from Lyon into Dauphiné. ${ }^{21}$ Despatches to and from the Swiss cantons were served by a relay from Lyon to Soleure and Coyre from at least 1548 . Those to Romans also had a relay route (6 relays), whilst a further axis went through to Grenoble with a choice of two routes (8 relays, the more direct including two "dangerous forests" and a "bad road"). From Grenoble, a route carried on to Gap (9 relays, involving a difficult river crossing and a mountain pass), Embrun and Briançon (8 relays). From there, travelling eastwards from Briançon to Montgenèvre there were two routes to Savoy. A northerly one crossed the mountains to join the Dora Riparia and onwards to Turin. The southerly route crossed the mountains via the Pregalato ('Pregalla') pass to Pignerol (Pignerola) and on to Turin or down to Saluces (Saluzzo) -26 relay points from Lyon to Saluzzo. An alternative and shorter route passing across the col de Lauteret to Briançon was also available by $1572 .{ }^{22}$ That was significant

18 Eugène Vaillé, 'Les maîtres de postes et les routes postales sous l'ancien régime. —1. De l'an 1464 à l'an 16oo', Bulletin d'information ... des P.T.T. (1937), p. 44 (citing an ordinance of François I of 5 July 1527).

19 Eg. XVIII-202 (avis, 12 August 1572).

20 XVII-273-4 ([Antoine] Grolier-Gordes; Lyon, 13 July 1572).

21 Jean Bonnerot, ed., Charles Estienne. La Guide des Chemins de France au XVIe siècle, 2 vols. (Paris: Bibliothèque de l'Ecole des Hautes Etudes, 1935-6), 1: 167-1812; 2: 165-75; cf. Robert Mandrou, 'La France de Charles Estienne', Annales. E.s.C., 16 (1961), pp. 1121-30. ACK XVII-263 (certificate of the provision of post-horses on this route from Crespin Bosc, vi-châtelain of Oysens and the greffier of the châtellenie, Jehan Villar, 12 July 1572). 
because dissident Protestants could disrupt the Pregalato. ${ }^{23}$ Grenoble was also linked to Chambéry by a relay involving four river crossings and across the St Jean-de-Maurienne pass to Susa and Turin, the principal residence of the dukes of Savoy. That replaced a more direct post route to Chambéry, abandoned when France ceded Piedmont back to Savoy in $1559 .{ }^{24}$ The most important post road, however, followed the Rhône southwards from Lyon, through Vienne, to Valence ( 8 relays and the crossing of the Isère and the Durance) and Montélimar (3 relays) before crossing the Rhône to avoid entering the territories of the Papacy at Avignon and carrying on to Nîmes or Aix and Marseille. The post between Lyon and Salon involved 28 relays. ${ }^{25}$ Letters from the Parlements in Aix-en-Provence and Toulouse, as well as from the governors and lieutenants in the Midi mostly passed up and down this route. The postrelays were expensive, but they worked. ${ }^{26}$

Gordes' correspondence carries endorsements noting the date when each despatch was received. From these we can calculate the comparative journey times of despatches, bearing in mind that letters often waited around for a courier and that endorsements are only accurate to the day. There was a seasonal variation because of travelling conditions in winter, especially with snow in the Alps. The calculations exclude letters arriving within 24 hours. ${ }^{27}$ Delivery times to Grenoble from Saluzzo in the eastern side of the Alps were, very surprisingly (given the possibilities of winter snow) the fastest. Those to Paris were close to the average. It was possible, although it did not often happen, for a despatch to take only five days. ${ }^{28}$ Those between the other southern provinces and Dauphiné were quite speedy, although it could sometimes take a month for despatches to transit from Toulouse, Bordeaux, Aix-en-Provence or Marseille to Grenoble. ${ }^{29}$ Gordes' correspondents expected the posts to work,

23 ACK XIX-260-1 (Soffrey de Boczosel—Gordes, Paris, 11 December 1572).

24 Vaillé, 'Les maîtres de postes', p. 55 ; cf. Vaillé, Histoire générale, 2: 90.

25 Vaillé, Histoire générale, 2: 92.

26 The standard cost was $5^{\circ}$ sous per relay—see Bibliothèque municipale de Grenoble, MS 7173, fo. 322v (mandates from Gordes for repayment of postal services in 1574).

27 Distances have been established with the help of Google Maps and the use of an opisometer on the map produced by the Laboratoire de cartographie de l'école pratique des hautes études from Charles Estienne's information (Annales, 1961). The latter gives lower readings.

ACK XVII-277 (Soffrey de Boczosel—Gordes, Paris, 13 July 1572), received in Grenoble on 18 July.

29 E.g. ACK XVII-178 (Honorat de Savoie, comte de Tende-Gordes, Marseille, 6 June 1572), received in Grenoble on 11 July; XIX-202 (Claude de Simiane-Gordes, Aix-en-Provence, 29 November 1572), received in Grenoble on 27 December; XVIII-6o (M. Blanieu to 
however, and complained when they did not. ${ }^{30}$ The letters that circulated between them governed the way that Gordes and the provincial notables worked. They monitored where other individuals were, and knew whom to trust when they received letters from them. They adjusted their days to expect letters which arrived as evening fell, deciding how much to keep to themselves, and how much to divulge.

Within Dauphiné, most of the letters in Gordes' post bag that were not from members of his own family came from those in authority in the towns. Most, though not all (e.g. Crest; Die), were on a post road. Most places in the province were not more than five days away from Grenoble. Within the province, despatches from Gap and Embrun travelled the slowest.

TABLE 27.2 Comparative journey times of letters in the Gordes Collection. (a) Extra-Dauphiné

\begin{tabular}{|c|c|c|c|c|}
\hline Trajectory & $\begin{array}{l}\text { Average } \\
\text { distance } \\
\text { travelled by } \\
\text { despatches } \\
\text { [in kms] }\end{array}$ & $\begin{array}{l}\text { Average } \\
\text { distance } \\
\text { travelled } \\
\text { per day } \\
\text { [in kms] }\end{array}$ & $\begin{array}{l}\text { Number of } \\
\text { despatches } \\
\text { in the } \\
\text { sample }\end{array}$ & $\begin{array}{l}</>\text { Variation } \\
\text { in the Overall } \\
\text { Coefficient } \\
{[1=38.42 \mathrm{kms} /} \\
\text { day }] \text { of aver- } \\
\text { age distance } \\
\text { travelled by all } \\
\text { endorsed letters }\end{array}$ \\
\hline $\begin{array}{l}\text { Paris-Dauphiné [Grenoble, } \\
\text { Laval, Allières, etc] }\end{array}$ & 614.14 & 62 & 78 & {$[>] 1.61$} \\
\hline $\begin{array}{l}\text { Saluzzo-Dauphiné [Grenoble, } \\
\text { Laval, etc] }\end{array}$ & 279.88 & 73 & 17 & {$[>] 1.92$} \\
\hline $\begin{array}{l}\text { Lyon-Dauphiné [Grenoble, } \\
\text { Laval, Allières, etc] }\end{array}$ & 118.45 & $27 \cdot 5^{2}$ & 33 & {$[>] 1.39$} \\
\hline $\begin{array}{l}\text { Provence and Avignon- } \\
\text { Dauphiné [Grenoble, Laval, etc] }\end{array}$ & 251.33 & 26.18 & 15 & {$[<] .68$} \\
\hline $\begin{array}{l}\text { Lower Languedoc [Montpellier, } \\
\text { Beaucaire]-Dauphiné } \\
\text { [Grenoble, Laval, etc] }\end{array}$ & 278.89 & 18.61 & 9 & {$[<] .48$} \\
\hline
\end{tabular}

Gordes, Bordeaux, 22 July 1572) received at Laval on 19 August ; XIX-282 (Pierre DemursGordes, Toulouse, 14 December 1572), received at Grenoble on 10 January 1572.

E.g. XVII-228, 6 July 1572; XVII-272, 13 July 1572. 
TABLE 27.2 Comparative journey times of letters in the Gordes Collection. (b) Intra-Dauphiné

\begin{tabular}{lllll}
\hline $\begin{array}{l}\text { Town [to } \\
\text { Grenoble] }\end{array}$ & $\begin{array}{l}\text { Distance } \\
\text { [from Grenoble } \\
\text { in kms] }\end{array}$ & No of days & $\begin{array}{l}\text { Number of } \\
\text { letters in } \\
\text { sample }\end{array}$ & $\begin{array}{l}</>\text { Variation in the Overall } \\
\text { Coefficient [1=38.42 kms/day] } \\
\text { of average distance travelled } \\
\text { by all endorsed letters }\end{array}$ \\
\hline Vienne & 105 & 5.667 & 3 & .48 \\
Briançon & 116 & 4 & 1 & .75 \\
Romans & 80 & 2.66 & 3 & .78 \\
Montélimar & 141 & 4.5 & 2 & .81 \\
Die & 99 & 3 & 1 & .85 \\
Valence & 92 & 2.4 & 4 & .92 \\
Crest & 111 & 3 & 1 & .96 \\
Gap & 124 & 3 & 6 & 1.07 \\
Embrun & 134 & 2.25 & 4 & 1.55 \\
\hline
\end{tabular}

Much of the information traffic in the province, however, moved from town to town, and quickly. That is implicit in how news of the Paris massacre reached Gordes, and how it spread thereafter. The story is incomplete, but it is worth examining the surviving evidence because Gordes' modern reputation rests upon it. News of the carnage arrived four days later in Lyon in the early hours of 24 August. $^{31}$ On 28 August, Gordes' regular correspondent from just outside the city at Saint-Symphorien d'Ozon wrote to him urgently with what he knew. That letter arrived the following day at Moirans, where Gordes was staying: ${ }^{32}$

As I was on the Rhône bridge at eight o'clock in the morning, I found the gates of the town closed and the drawbridge raised. Some of those leaving town told me that it was because a courier had come arrived from Court bringing news ... that someone had killed the Admiral ... and others of note, and that there had been a great blood-letting, and that Monsieur de Guise was injured, all of which happened in Paris. The news has been cried around the streets of Lyon and those of the Religion [viz. Protestants] do not stir from their houses believing that Catholics are taking up arms in large numbers.

31 Antoine Péricaud, Notes et documents pour servir à l'histoire de Lyon (Lyon: Pélagaud, Letne et Crozet, 1838), pp. 71-5; Alexandre Puyroche, 'La Saint-Barthélemy à Lyon et le gouverneur Mandelot', Bulletin de la société de l'histoire du protestantisme français, 38 (1869), pp. 305-23; 353-67.

$32 \quad$ ACK XVIII -282. 


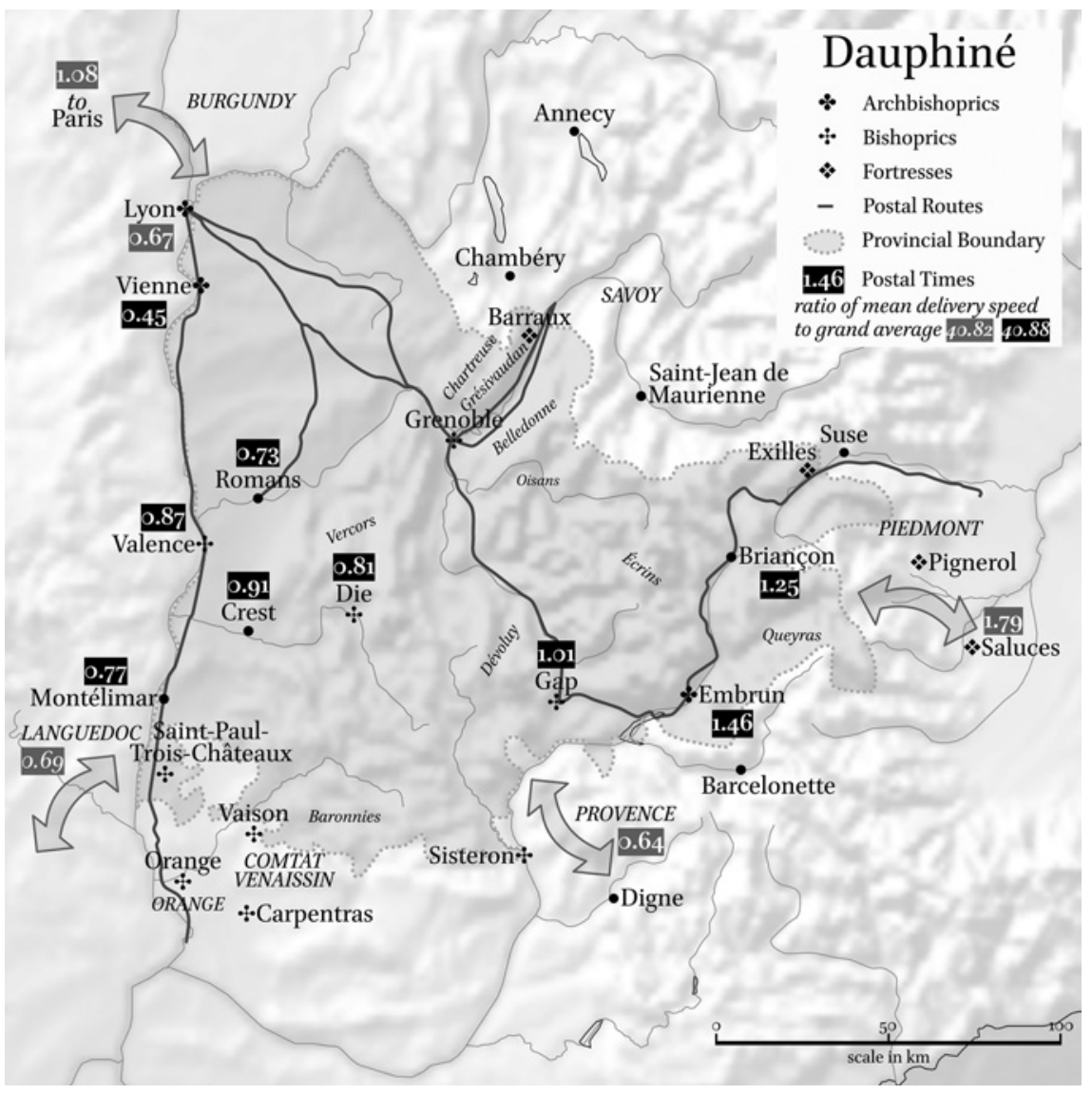

FIGURE 27.4 Map of Dauphiné. Note that Barraux only became a truly fortified site at a later date, after 1597 .

Later that day, the news also arrived in Vienna, from where Annet de Maugiron, the governor of the town since 1568 , wrote to Gordes, giving him an account of the security measures which he had instigated there. ${ }^{33} \mathrm{He}$ wanted to reassure him that he was protecting Protestants in the town in order to allay any suspicions that Gordes might have. The news reached the second président of the Parlement in Grenoble, Guillaume de Portes, via Gordes, whose courier arrived there late on the evening of 28 August. ${ }^{34}$ Gordes despatched a series of letters throughout the province that evening. ${ }^{35}$ The following morning, however, and

33 ACK XVIII-284.

34 ACK XVIII-286. For the career of de Portes, see Fleury Vindry, Les parlementaires français au XVIe siècle, 2 vols (Paris: Honoré Champion, 1909-12), 1: 70.

35 E.g. Baron de Coston, Histoire de Montélimar, 2 vols. (Montélimar, 1883), 1: 336-7. 
before de Portes had a chance to meet the first consul of the city, "rumour was abroad in that town of some stirrings and notably that the Admiral had been injured". ${ }^{6}$ They originated from a lackey of Balthasar de Combourcier, sieur du Monestier, a Dauphiné noble, then in Paris. However, they were already embroidered: "By contrast others said that his murder had been instigated by someone from higher up and that they had wanted, but failed, to attack the king". A Protestant accosted de Portes as he left his house in the morning, wanting to know whether he should pack his bags and seek safety elsewhere. To reassure him, de Portes said that, whilst Catholics were in arms, it was to ensure the safety of everyone.

Meanwhile, that same day, the consuls of Vienna passed the news from Paris down to Valence, whose consuls wrote in haste to Gordes to report on the extra searches at the gates and patrols within its walls. Such measures were necessary because "in this town there are numerous foreigners, which Protestants lodge in their houses as servants or such like, giving them work to do in their chambers". ${ }^{37}$ They could not absolutely guarantee, despite their best endeavours, that their city was safe from Protestant reprisals. That same day (29 August) Gordes also received two despatches from the king, dated 22 and 24 August, copies of which he forwarded to de Portes in Grenoble. The content of the second letter is well known since it survives in copies to other governors. Charles IX described the assassination of leading Protestant nobles at Court and blamed it on the rivalry between the Protestants and the house of Guise. He asked local leaders to take all possible measures to have the edict of pacification observed to the letter. ${ }^{38}$ Gordes ordered copies of the king's letter, or perhaps an extract of it, to be distributed to local leaders.

Were there, however, other, secret verbal instructions from the king? The possibility cannot be ruled out. In a memorandum by the seigneur de Vaucluse, a nobleman in the entourage of the comte de Tende, governor of Provence, there is an account of how the king despatched Joseph de Boniface de la Molle as a courier to Provence on 24 August. He carried instructions to eliminate all the Protestants in that province. His letters also included, according to Vaucluse, an additional autograph postscript in the king's hand, countermanding

36 ACK XVIII-287; cf XVIII-286 (Séverin Odoard-Gordes, Grenoble, 29 August 1572).

37 ACK XVIII-289.

38 Mémoires de l'estat de France sous Charles IX. Contenans les choses plus notables, faites \& publiees tant par les Catholiques que par ceux de la Religion (Heidelburg, 1578), 1, 296-9 Cf. L. Cimber and F. Danjou, Archives curieuses de l'histoire de France (Paris, 1834-40), 1st series, vol. 7 , pp. 157-8. 
all that the letter ordered. ${ }^{39}$ If true, this reflects the confusion prevailing in and around the king as they assessed the impact of what was happening around them. Charles IX was subjected to contrary pressures from (on the one hand) his younger brother Henri Duke d'Anjou (to whom Boniface de la Molle was beholden) and, on the other hand, his mother, Catherine de Médici. Boniface de la Molle would have carried that letter through Lyon (where the consuls were apparently informed by their syndics in Paris that it was the king's intention that the massacre should be replicated in provincial cities) and then down the Rhône. There, too, its confusing contents may have been revealed. If so, Gordes' correspondence indicates that his efforts to countermand it seem to have worked. A message arrived from Gordes in Romans, for example, on the morning of 29 August at about 8:00 am, brought there in person by the governor of Montélimar, Jean de Dorgeoise, sieur de La Thivolière, one of Gordes' gens d'armes. ${ }^{40}$ He was followed very soon afterwards by a "courier coming from the Court". The consuls were anxious for Gordes to understand that they were following his instructions. At Valence, the consuls received the same message at around midday that same day, also from La Thivolière, riding down from Romans. ${ }^{41}$ However, the head of the garrison in Valence, Captain Loriant explained that he had already received the news from Vienne and armed "a number of Catholics in the town" as a defensive measure. ${ }^{42}$ In both Valence and Romans the local authorities hesitated as to whether they were supposed to call to arms the Catholic population (and follow the lead of Paris) or do so in order to secure the peace (to forestall what had transpired in the capital). In Montélimar, Rostaing d'Ourches, Gordes' son in law (sent there with the 28 August letters) attended a town council meeting with representatives from both religions. He assured Protestants that Catholic citizens had been authorised to carry arms "not to harm anyone, least of all to discomfort them, but simply to ensure that there was no uprising ..."43

Other copies of the despatches from Gordes went to distant parts of the province. Those for Crest, for example, did not get beyond Valence by 3.oopm on 29 August, and the consuls of the town sent them on "by express courier" whilst a messenger in the service of the vicar-general of the bishop of Grenoble

39 J. de Teil, ed., 'Livre de raison de noble Honoré du Teil (1571-1586), Bulletin de la société scientifique et littéraire des Basses-Alpes, 6 (1893-4), pp. 30-3. See Philip Benedict, 'The St Bartholomew's massacres in the provinces', Historical Journal, 21 (1978), pp. $201-5$.

$40 \quad$ ACK XVIII-291.

41 ACK XVIII-292.

42 ACK XVIII-293.

43 Coston, Histoire de Montélimar, pp. 337-8. 
carried them to Gap. ${ }^{44}$ The professor of civil law at the University of Valence at the time was Joseph Justus Scaliger. In a collection of writings attributed to him, compiled in the following century by Pierre Dupuy and published in 1666, Gordes was quoted as replying to orders from the king to eliminate the province's Protestants: "il n'était pas un bourreau; qu'il commandait à d'honnêtes gens et non pas à des assassins" ("that he was no executioner; that he was in charge of honest people, not assassins". $)^{45}$ The sentiments may reflect a contemporary assessment of how his command of the information environment, particularly in the Rhône valley, prevented a bloodbath. However there is no evidence that he himself ever received such orders from the king, and no direct proof that they had circulated in the province either.

$$
* * * * *
$$

These days in late August 1572 indicate with what detail one can pursue the flow of information in the Gordes network at a crucial juncture. If we now widen the focus of the lens we can substantiate three general points that emerge from the study of this correspondence, ones which are relevant to the study of newsletters. They may be expressed as truisms. The first is that princely courts were places where 'hard' information was in scarce supply. Its 'rarity' was therefore a function of a state of permanent contingency. The second is that all information was to be regarded as 'soft' until it could verified by a 'triangulation' of confirmatory elements, coming from different sources. The third is that, when it came to wanting to know what was going on, nothing beat having someone local keeping their ears to the ground.

Gordes' informants at the French court included provincial agents as well as members of his family. No one corresponded with the regularity of his own agent, Soffrey (i.e. 'Geoffrey') Boczosel. ${ }^{46}$ Rarely a week passed without a letter bearing his signature among Gordes' papers. Structured like newsletters, Bocsozel's missives worked through issues systematically, dividing family from public information, domestic from foreign news. He had good connections at Court. His letters recount his audiences with the king and queen mother, as

44 ACK XVIII-289 (de Portes-Gordes, Grenoble, 30 August 1572); 292 (consuls de ValenceGordes, 30 August 1572).

45 Scaligeriana (1666), p. 96. De Thou had an echo of the same account, since he reported that Gordes refused to execute the king's orders to eliminate Dauphiné's protestants because it would be too dangerous to do so (Jacques-Auguste de Thou, Histoire universelle, 16 vols. (Londres, 1743) (book 52), 6: 428). Cf. Jules Taulier, Notice historique sur Bertrand-Raymbaud Simiane, baron de Gordes (Grenoble, 1859), pp. 89-93; Comte de Quinsonas, Le baron de Gordes et la Saint-Barthélemy en Dauphiné (Grenoble, 1955). 
well as the secretary of state with responsibility for Dauphiné, Simon de Fizes. ${ }^{47}$ He attended outside the royal council on the appointed days for Dauphiné affairs. Not much happened in the province that escaped his attention.

Despite his connections, Boczosel had difficulty reading the runes about affairs at the French Court. There was a structural difficulty for any observer in his position. ${ }^{48} \mathrm{He}$ observed the comings and goings, and the movements of the Court itself. Yet he could read little into such matters, unable to predict what would happen next. On affairs that concerned Gordes, he was frustrated by delays, unfulfilled promises, and unexpected complications. Even the straightforward matter of issuing letters of provision for Gordes to become commander of Grane dragged on. This fortress on the Drôme River had belonged to Diane de Poitiers. Following her disgrace, it served as a Protestant redoute until Gordes secured its negotiated surrender in December 1570. He was granted it as a reward, and had already installed a garrison there. Securing the necessary letters of provision was another matter, however, absorbing the energies of Gordes' uncle, Gaspard de Simiane, in the later months of $1572 .{ }^{49}$ On national and international affairs, too, Boczosel tempered his reading of them with contingency and hesitation. That was partly because there was indecision at the French Court itself. The French king hesitated over the summer about whether to back a military intervention in support of the landed invasion of the Netherlands masterminded by William of Orange. After August 1572, the uncertainty turned upon whether France's Protestants would take up arms in response to the massacre of Saint Bartholomew. Gordes' brother, Aimar de Simiane, was resident in Paris and sometimes attended Court. He reckoned (16 June) that war with Spain was on the cards, and warned his brother to prepare for its consequences. ${ }^{50} \mathrm{~A}$ week later, however, with news of the arrival of Juan de la Cerda, Duke of Medinaceli in Flanders, accompanying large Spanish reinforcements, Boczosel was less sure: "those with the greatest understanding can often be wrong about an event".51 That same day another Gordes correspondent at Court lamented that "it is the same old uncertainty; today universal

47 E.g. ACK XIX-247 (Simon de Fizes-Gordes, Paris, 8 December 1572).

48 See Denice Fett, 'Information, Gossip and Rumor: The Limits of Intelligence at the Early Modern Court, 1558-1585', in The Limits of Empire: European Imperial Formations in Early Modern World History, ed. Tonio Andrade and William Reger (Aldershot: Ashgate, 2012), pp. 79-98.

ACK XIX-22 (Gordes-M. de Briançon, Laval, 3 October 1572); XIX-109 (Gaspard de Simiane-Gordes, Paris, 15 October 1572); XIX-172 (ibid., 19 November 1572).

50 ACK XVII-177 (Aimar de Simiane [M. de La Roche]—Gordes, Paris, 16 June 1572).

$5^{1}$ ACK XVII-186 (Soffrey de Boczosel—Gordes, Paris, 22 June 1572) — 'l'événement le plus souvent trompe les plus grandz entendementz' 
peace, tomorrow, general war". ${ }^{52}$ The news of the attack on Medinaceli's forces at Sluys, initially exaggerated among Gordes' correspondents in Paris, did little to change their bafflement as to the direction of French affairs. ${ }^{53}$ For the reality was that it depended on the outcome of negotiations in England and on a resolution of contradictory pressures around the French council table. For the present, those in authority in France let the issue be vague. Writing from Paris on 24 June 1572, Jean des Aymards expressed his frustrations to Gordes:

I might dare to advertise your lordship of the talk which flies around both from Flanders as well as from the ambassadors based here, or those which have just recently returned from the Turks. Yet since it is talk that seems to have little substance to it, I would be better advised to keep my own counsel and, rather than fill up the paper with palace inventions which have no merit, wait for something more vital and worthy to write to your highness ... ${ }^{54}$

"Festina lente" ("make haste slowly") was a catchphrase of royal councillors. Whilst time did its work, however, those in the business of handling news were left swinging in the wind.

One of Boczosel's tasks at court was to protect Gordes' reputation. Partly because of the opacity of Court affairs, he detected the hand of detractors in every setback he encountered. He trusted in the "good opinions" of Charles IX and Catherine de Médici, their willingness to respond favourably to requests, and to protect his patron against these unnamed "enemies". When the queen mother treated Gordes' recently acquired son in law, Rostaing d'Eure, sieur d'Ourche to an audience over supper, Bocsozel's agent M. de Taillardet was relieved. A petition from Dauphiné's Protestants at Court in July 1572 offered, however, the possibility for Gordes' detractors to argue that, far from successfully implementing the 1570 edict of pacification, he had acted with partiality.55 At the end of July, Boczosel anxiously reported to Gordes that Admiral Coligny had used the petition to call in question Gordes' handling of affairs before the royal council. ${ }^{56}$ Neither Boczosel nor others in Gordes' entourage were convinced that they had put to rest the criticisms of his behaviour. They

\footnotetext{
52 ACK XVII-187 (M. de Taillardet-Gordes, Paris, 22 June 1572).

53 ACK XVII-191 (M. d'Ourches-Gordes, Paris, 25 June 1572); 192 (Chastellard-Gordes, 26 June 1572).

54 ACK XVII-176.

55 ACK XVIII-39 (Soffrey de Boczosel-Gordes, Paris, 19 July 1572).

56 ACK XVIII-104 (Boczosel-Gordes, Paris, 30 July 1572).
} 
advised him to mount a defence of his actions in the form of a letter to the king, which he should be prepared to spread abroad in due course. ${ }^{57}$ Thanks to his contacts at Court, Gordes knew, as he sought to calm the fears of the province's Protestants in the wake of the massacre of Saint Bartholomew that he might need to justify his conduct by means of a libel, just as other lieutenants and governors in the recent past had also done.

The practice of information 'triangulation' appears at every juncture in Gordes' correspondence. Since we do not have his outgoing correspondence, we can only reconstruct the processes incompletely. They are particularly evident, however, where eyewitnesses were few, and where observation platforms were numerous and indirect. That was the case in respect of naval affairs in the Mediterranean in the summer of 1572 . Gordes received intelligence from merchants and seamen in France's Mediterranean ports-especially Marseille, Toulon and Aigues-Mortes. There was also information from Genoa, Florence, Rome and Venice, flowing through Saluzzo. This was supplemented by reports from the French ambassador at Constantinople. News about major Turkish naval manoeuvres in the Aegean was of particular importance to the French Court since its decision about an intervention in the Netherlands hung, to a considerable degree, on an assessment of how much Spain's attentions would be deflected from the rebellion in northern Europe to handle the crisis in the Mediterranean. ${ }^{58}$ Not until early July, however, did accurate figures of the extent of Admiral Aluj Ali's fleet become available to Gordes. ${ }^{59}$ Above all, there was uncertainty about the precise whereabouts of Spain's galley fleet, and whether its leader, Don John of Austria, would be permitted by Philip II to commit his forces to a joint naval campaign with the Venetians and other allies of the Holy League. ${ }^{60}$ That was what had happened the previous year, at Lepanto, the news of which had arrived in Gordes' network as flatly contradictory reports, first of a victory, and then of a defeat. Only by evaluating the various sources did the nature and scale of the victory become evident. By mid-July 1572 it was becoming evident to the seasoned watchers of Mediterranean affairs around Gordes that Philip II's caution was itself a reflection of his assessment of French irresolution in respect of Flanders, each contributing to the intensifying pressure-cooker atmosphere of

57 ACK XVIII-161 (Boczosel-Gordes, Paris, 6 August 1572); cf. XVIII-214 (14 August 1572).

$5^{8}$ See Geoffrey Parker, 'Spain, her enemies and the Revolt of the Netherlands, 1559-1628', Past and Present, 49 (1970), 72-95; and The Grand Strategy of Philip II (New Haven: Yale University Press, 1998).

59 ACK XVII-265 (Mathieu Bovier-Gordes, Saluces, 12 July 1572).

6o ACK XVII-219 (Bellièvre-Gordes, Montpellier, 5 July 1572); XVII-227 (Pierre BonGordes, Marseille, 5 July 1572); XVII-228 (Guillaume d'Avançon-Gordes, Embrun, 6 July 1572); XVII-233 (Mathieu Bovier-Gordes, Saluces, 7 July 1572), etc. 
international affairs in the summer of 1572. By then, however, the Venetian fleet under Jacopo Foscarini had sailed to the Aegean with a limited contingent of Spanish vessels provided by Don John. How should this be interpreted? Gordes' intelligence pointed in different directions. Some commentators thought the Spanish commander had left for the Aegean in late July, others that he was still in Messina, or en route for Genoa. Only gradually, and by a process that was rather akin to filtering out surplus noise, did it become evident that (although the rumours of his embarcation for Genoa were false) Don John had not left for the Levant but was preparing for an expedition to Tunis. Once the news of the massacre of Saint Bartholomew reached Madrid, however, Don John was given leave by Madrid to join Foscarini's naval forces in Corfu, the evidence for which was monitored by Gordes' agents through the autumn and early winter of 1572 .

Gordes' correspondents monitored the tempo in various parts of the province, and especially gauged the dispositions of its Protestants. That was not easy, even for someone like Gordes whose family had connections with the Protestant nobility. Synods and consistories were not supposed to discuss politics, and the pacification of 1570 had outlawed their holding assemblies for other than religious matters. The petition that Protestants presented at Court in July 1572 took Gordes' servants by surprise. The Protestant nobility of the region was scattered and divided-especially after the defection (and subsequent deposition) of their leader in the first civil wars, the Baron des Adrets. His place was taken by Charles Dupuy, sieur de Montbrun, who belonged to the active political wing of French Protestantism. His château at Montbrun was razed to the ground on the eve of the Civil Wars, but he himself escaped to the south of Dauphiné and fortified the castle of La Gabelle at Ferrassières. That place put him close to the Protestant stronghold of Les Baronnies, that part of Provençal Dauphiné east and north of the Mont Ventoux. Gordes' correspondents picked up signals of unusual movements of carriers, horses and belongings around Montbrun. They listened out for meetings and associations, and the circulation of rumours. Much of this intelligence probably did not make it further than Gordes' own secretariat, but it remained essential to the security of the province.

Through the summer of 1572, Gordes' informants monitored those Dauphiné Protestants who joined the expeditionary force of 10,000 soldiers which Louis of Nassau's co-adjutant, Adrien de Hangest, sieur de Genlis assembled in France, an army that met with disaster at Mons in July 1572. In fact, by the time the contingent led by Montbrun was ready to muster, the disaster at Mons had probably already taken place. ${ }^{61}$ From various quarters in the Rhône valley,

61 ACK XVII-268 (Montoison-[Jean] Truchon, Montoison, 13 July 1572). Cf XVIII-20 (Mandelot—Gordes, Lyon, 17 July 1572); XVIII-24 (Suze-Gordes, Suze, 17 July 1572); XVIII-38 ([Jean de] Bellièvre-Gordes, Montpellier, 19 July 1572). 
however, came reports of 'secret and public assemblies of those who call themselves God's children, or the Reformed religion'. ${ }^{62}$ Those seemed to be linked to the petition. They heightened alarm among Catholics.

After Saint Bartholomew, the monitoring took on a different dimension. In communities across the province, Protestants surrendered their arms in return for protection and prudently converted back to the Catholic religion. According to the Bishop of Embrun, even some of the elders of the consistory court at Fressinières, Montbrun's own church, expressed a willingness to do so. ${ }^{63}$ From Exilles in the Susa valley of Piedmont, supplied with pastors and support from Geneva, resistance emerged from the end of September. ${ }^{64}$ The premier président reported that Protestants at Saint-Bonnet-en-Champsaur staged a protest against re-Catholicisation. ${ }^{65}$ Would Montbrun chose to mobilise Dauphiné's Protestants in a new war? Gordes relied on the fact that Montbrun was his relative (through Gordes' wife Guyon Alleman). Montbrun assured him of his loyalty, despite solicitations to join the revolt which begun to take shape at La Rochelle and in Lower Languedoc in October. ${ }^{66}$ From Orpierre in Les Baronnies Gordes received intelligence, however, that Montbrun was preparing to attack. He had assembled over 2,00o soldiers and 200 cavalry. The message to rise passed from farmstead to farmstead in the High Alps. ${ }^{67}$ At Crest, Gordes' relative Louis d'Urre reported that the consuls of the town had arrested a messenger from Montbrun carrying "a little book sewn up and disguised as a memory stone". The messenger confessed under interrogation to being about the business of Montbrun. He tried unconvincingly to say that the "little book" (possibly a draft Protestant 'association' of the kind that was being circulated around Lower Languedoc) was something which he had picked up en route. ${ }^{68}$ From Mirabelles-Baronnies came the report of a messenger arrested carrying "a letter folded very small in an extraordinarily intricate way, into a little ball of green wax,

62 ACK XVIII-96 (Clément Faure-Gordes, Valence, 28 July 1572); XVIII-114 (Andrieu de Exea-Gordes, Grenoble, 31 July 1572).

63 ACK XVIII-314 (Consuls of Orpierre-Gordes, 24 September 1572); XVIII-319 (Guillaume d'Avançon-Gordes, Embrun, 25 September 1572) ; XvıII-321 (Rostain d'Urre-Gordes, Montélimar, 26 September 1572), etc.

64 ACK XVIII-323 (Jean Borel, sieur de La Casette-Gordes, Exilles, 27 September 1572).

65 ACK XIX-30 (Guillaume de Portes-Gordes, Grenoble, 3 October 1572).

66 ACK XIX-92 (ibid., Grenoble, 13 October 1572); XIX-195 (Montbrun-Gordes, Montbrun, 28 November 1572).

67 ACK XIX-54 (M. de Villefranche-Gordes, Orpierre, 6 October 1572); XIX-57 (M. Du Pègue-M. d'Ourches, Le Pègue, 5 October 1572); XIX-69 (La Thivolière-Gordes, Valence, 8 October 1572).

ACK XIX-66 ([Louis] d'Urre-Gordes, Crest, 8 October 1572). 
shaped like an olive". ${ }^{69}$ On investigation, this disguised missive to Montbrun, sent from Louis de La Marette, sieur de Pierregourde, a militant Protestant noble across the Rhône in the Vivarais, contained a document revealing Protestant military preparations. The governor in Languedoc, Henri de Montmorency-Damville, had received a copy of it too. He was sceptical towards Gordes' willingness to take Montbrun's assurances on trust. The evidence from the ground pointed in another direction. ${ }^{70} \mathrm{He}$ was proven right when Montbrun raised the standard of revolt in the spring of 1573 .

$* * * * *$

This investigation of the surviving correspondence of a royal lieutenant in a frontier province of France during the wars of religion is a reminder of the practicality and significance of letters in the information-flows of a noble clientele that were an essential governing reality to the French state. Gordes' network provided a way of collecting, collating and analysing intelligence on an international as well as a provincial stage. Newsletters were an adjunct to those information flows and, when we compare them with the way that a noble's correspondence was composed, carried, handled and received, cognate to it. Such correspondence continued to be the spinal column of French information networks. Renaudot's published Gazette only gradually supplemented these other, tried and tested letter-sources of information, circulating among the clienteles of France's governing élites. ${ }^{71}$

\section{Acknowledgements}

The authors acknowledge the financial assistance of the P.т.T. towards the research presented in this chapter, and the assistance of Peter Derlien in the preparation of the statistical tables.

69 ACK XIX-183 (The avocat and procureur du roi of the bailliage at Le Buis-Gordes, 26 November 1572).

$70 \quad$ ACK XIX-205 (Damville-Gordes, Beaucaire, 30 November 1572).

71 Stéphane Haffemayer, L'information dans la France du XVIIe siècle. La Gazette de Renaudot de 1647 à 1661 (Paris: Honoré Champion, 2002); Stéphane Haffemayer, 'Information et espace public: la presse périodique en France au XVIIe siècle', Revue de synthèse, 126 (2005), pp. 109-37. 